\title{
INFORMATION COMMUNICATION TECHNOLOGY FOR PROFESSIONAL DEVELOPMENT OF ADULT EDUCATION STAFF MANAGEMENT: CHALLENGES AND PROSPECTS IN THE SILESIA REGION
}

\author{
Luis Ochoa Siguencia \\ The Jerzy Kukuczka Academy of Physical Education in Katowice, Poland \\ Gilberto Marzano \\ ${ }^{2}$ Rezekne Academy of Technologies, Latvia \\ Damian Herman \\ The Jerzy Kukuczka Academy of Physical Education in Katowice, Poland
}

\begin{abstract}
This research focuses on the professional development of Adult Education Staff through the implementation of Information and Communication Technology skills. We present the data from a desk and field research carried out in the Silesia Region - Poland, on a sample formed of Adult educators working in different Non - formal Education Institutions. The research tool used in our paper is an online questionnaire developed withing the ERASMUS+ project "Upskillead-2016-1-SI01-KA204-021588” KA2 - Strategic Partnership in the field of Adult Education. The final research objective is to find solutions useful to develop digital competence of adult people through in-house training's, seminars and informal learning applications. Moreover, this paper illustrates benefits, limitations, challenges in using digital resources and tools in adult education.
\end{abstract}

Keywords: Adult education; Cooperation for innovation; Erasmus+; Information and Communication Technology; Strategic Partnerships.

\section{Introduction}

Information and communication technologies [ICT] uses a combination of devices and communication technologies. ICT include microelectronic and data transmission as well as fax machines, mobile phones, computers, cable television, information networks, video-Tex, software and online databases. Today's technological progress forces the society to becoming a knowledgebased society. Related to this fact we are confronted to the need of continuing necessity to acquire knowledge, science, technology and information.

The target group of "Upskillead - Upskilling Adult Educators Digital Lead" project, funded by the Erasmus+ Programme, KA2 - Strategic Partnership in the 
field of Adult Education, is Adult Educators involved in adult learning who will upgrade their digital skills and use of technology, whereas the indirect target group is adult learners, who will benefit from digitally literate teachers through the provision of high quality adult learning (UPSKILLED, 2016). Based on the above the project is in line with the Erasmus+ priorities for:-extending and developing educators' competences, particularly in the effective use of IT in adult learning, for better outreach and improved learning outcomes.

The first output is to benchmark research on Adult Learning: Mapping of Adult Learning provision and policies, adult learners' and adult educators' digital needs and requirements, professional development programmes for $\mathrm{AE}$, digital needs of the labour market to be acquired by adult learners.

Adult educators are aware that one ought to learn throughout theirs entire life, gaining daily experience that will impact in their future activities. To prevent an aging society, to prevent them from social exclusion, governments propose a number of programs and solutions that allow continuous education in adult generations.

Some examples of this action are showed in the table below:

Tab. 1 Adult education programs

\begin{tabular}{|l|l|l|}
\hline Action & Objective & Description \\
\hline $\begin{array}{l}\text { Solidarity between } \\
\text { generations }\end{array}$ & $\begin{array}{l}\text { to increase the activity of } \\
\text { people aged 50+. }\end{array}$ & $\begin{array}{l}\text { It is a package of governmental } \\
\text { actions aimed at increasing the } \\
\text { employment of elderly people in } \\
\text { Poland. }\end{array}$ \\
\hline $\begin{array}{l}\text { Strategy for } \\
\text { Europe 2020 }\end{array}$ & $\begin{array}{l}\text { to develop of all kinds of } \\
\text { Education System and } \\
\text { activation. }\end{array}$ & $\begin{array}{l}\text { Among the 5 goals proposed, one of } \\
\text { them deals with the possibility of } \\
\text { lifelong learning, regardless of the } \\
\text { age. }\end{array}$ \\
\hline $\begin{array}{l}\text { Governmental } \\
\text { Active Aging }\end{array}$ & $\begin{array}{l}\text { to create favourable } \\
\text { conditions for developing } \\
\text { social activity of older people } \\
\text { to maintain them in good } \\
\text { psycho-physical condition, } \\
\text { with potentials, qualifications } \\
\text { and ready to contribute with } \\
\text { their experience. }\end{array}$ & $\begin{array}{l}\text { Among the priorities about education } \\
\text { we can find: Priority I. Education of } \\
\text { older people - includes activities } \\
\text { aimed at developing the educational } \\
\text { offer addressed to seniors, exploiting } \\
\text { the potential of mutual learning and } \\
\text { the development of innovative forms } \\
\text { of education, including informal and } \\
\text { non-formal, promoting the so-called. } \\
\text { volunteer competences }\end{array}$ \\
\hline
\end{tabular}

Source: Based on information from „Government Program for Social Activity Ageing for 2014-2020” The Ministry of Family, Labour and Social Policy [https://www.mpips.gov.pl/seniorzyaktywne-starzenie/rzadowyprogram-asos (retrieved 31.01.2017)] 
In Poland, the seniors' Policy Department at the Ministry of Labour and Social Policy established under Ordinance No. 68 of the President of the Council of Ministers dated $16^{\text {th }}$ August 2012 is the responsible for the creation and development of activities related to seniors, improving the system of support, implementation of activities and tasks that support seniors activities, their education and activation in the society (DPS, 2016).

There are many organizations, associations, non-profit organizations, scientific circles operating in cultural centres that offer courses and training for elderly people (Budny et al., 2013). These organizations operate on the basis of their own regulations, statutes, contracts, but are not subject to the legal regulation in the field of the Education Act and Higher Education, but they have a Ministry that look after their activities and are able to control and ask for any information on their activities.

\section{Research methodology and presentation of field research}

The survey presented in this paper is the Polish partners' collection of data (qualitative and quantitative) within the Upskilling Adult Educators Digital Lead project, funded by the Erasmus+ Programme, KA2 - Strategic Partnership in the field of Adult Education. The project is been coordinated by Razvojno Izobrazevalni Center based in Novo Mesto (Slovenia) and involves 5 European partners. The electronic questionnaire, using SurveyMonkey, was passed to 55 teachers of Adult non-formal education Institutions in the Silesia region in Poland. The research was conducted in January 2017 and involved 34 women and 21 men. The age range within 20 to 64 years old.

Descriptive statistics were used for data analysis (descriptive statistics) and quantitative techniques (Little, 2013). To verify the hypothesis, that two qualitative characteristics of the population are independent the test $\chi^{2}$ was used, comparing the frequency of observed frequencies with the expected.

Where:

$\mathrm{O}_{i}=$ the number of observations of type $i$

$\mathrm{E}_{i}=$ the expected number of observations of type $i$

Also the Mann-Whitney $U$ test which is a non-parametric alternative to the t-test for independent samples:

Where:

$\mathrm{R}_{1}$ means the sum of ranks allocated to the values of the first attempts

$R_{2}$ means the sum of the values of ranks awarded second attempt

$\mathrm{n}$ is the total number of observations $\left(\mathrm{n}=\mathrm{n}_{1}+\mathrm{n}_{2}\right)$

To the question "How long ago was your last training /education activity to which your employer appointed you?" Almost $50 \%$ has determined that this was no more than a month earlier. Another $25 \%$ of respondents chose the 
option that approximately 3 months ago and an additional $11 \%$ that it was about a year ago. Arises from the result that $84 \%$ of staff was trained in the last year. A very good result. This can be explained, among others, that even school principals have special funds for training teachers

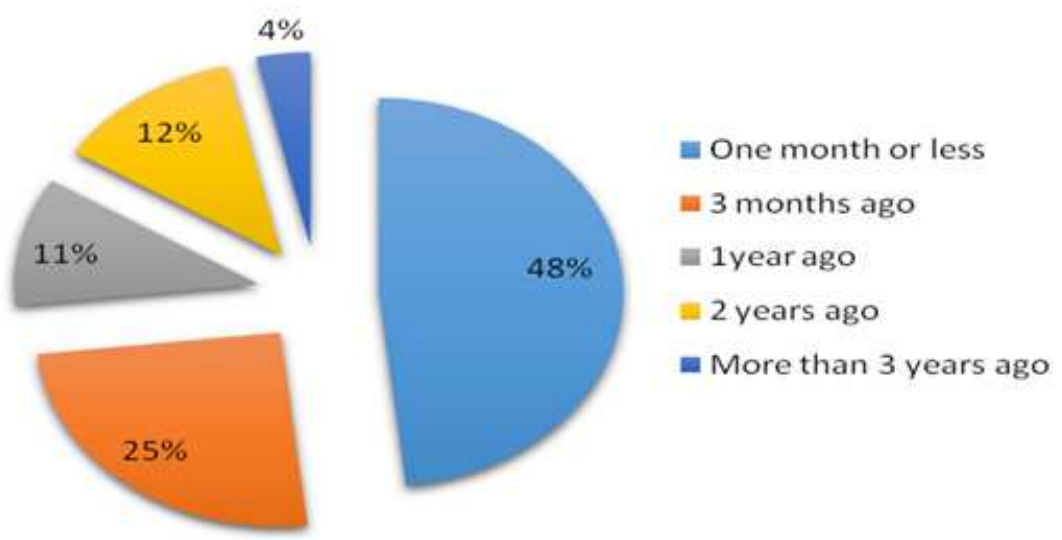

Figure 1 Participation in a training activity

This thesis is confirmed in the next question: „Name your reasons for your lack of knowledge regarding your job position" (see figure 2). Only 4 percent of respondents marked as the biggest obstacle the "limited financial resources of the company". What is alarming is that $15 \%$ of respondents consider that there is no need for further training. In times that it is dynamically changing and every person should be updated [continues learning].
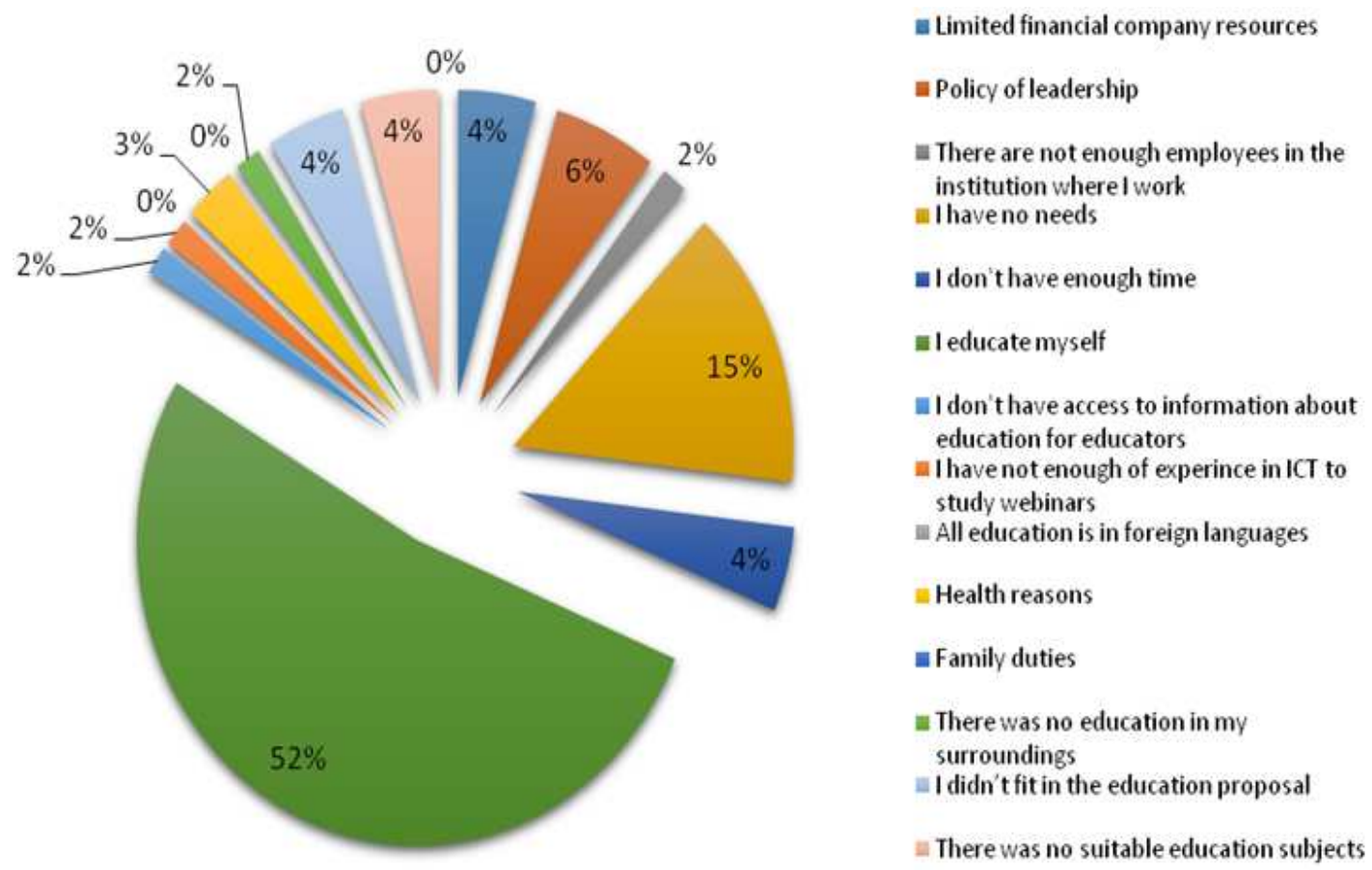

Figure 2 Lack of knowledge to perform a job 
It is surprising statement, that more than half of respondents (52\%) to the above question that they educate themselves. This would suggest that although the training, there is not enough knowledge on the specific area they should work. The reason for this lack of knowledge can be because there was not adequately tailored educational tools to be used by trained teachers.

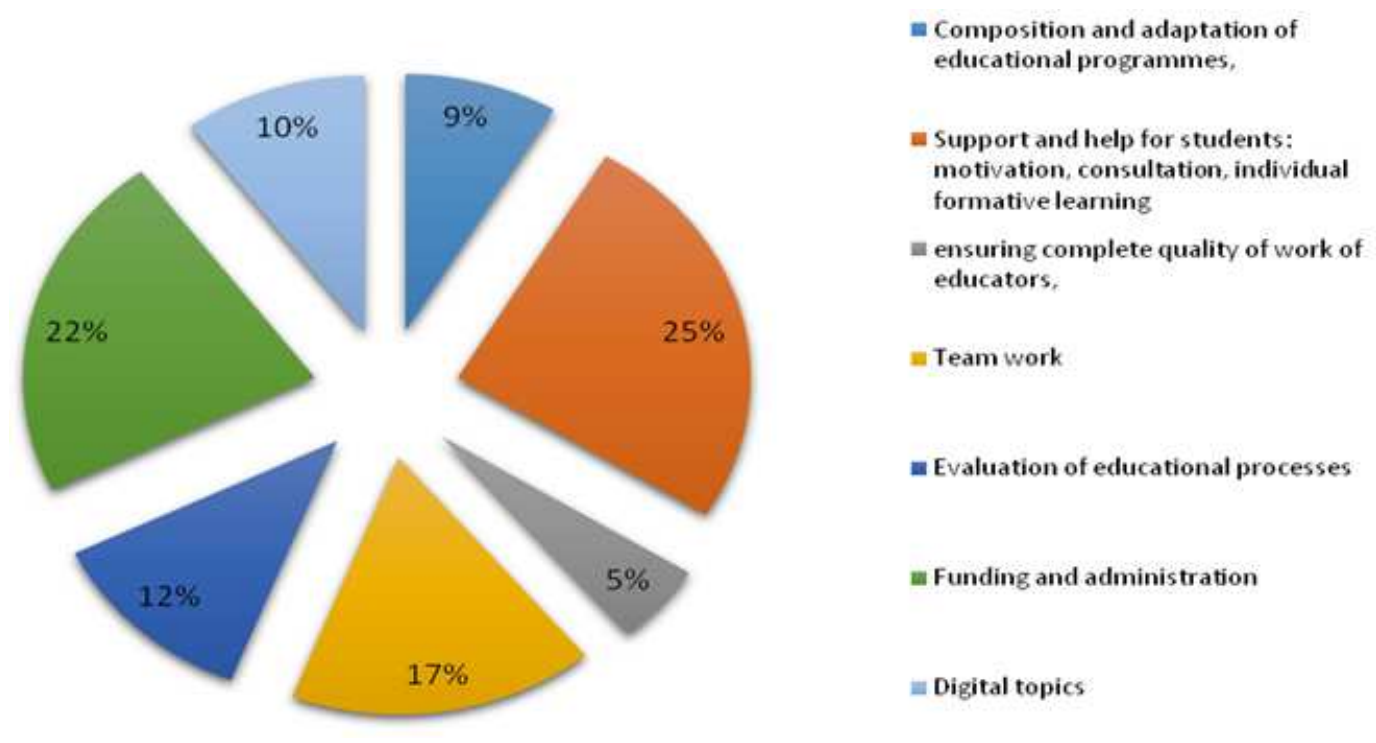

Figure 3 Lack of knowledge to perform a job

Moving on to the questions related to the issues of ICT can be interesting to point out that employees involved in adult education feel not very comfortable. In the responses to the question, At which tasks and competences at work do you feel weak, and you think that you need to be educated on most in order to be successful" there is not definitely a factor. However, most people $(25 \%)$ believe that their biggest problem is support and assistance for students, such as motivation and consultation. Can therefore be specify that the so-called. soft skills as even the ability of verbal and nonverbal communication, empathy, which are defined as significant in leading the training groups to success are still needed to develop them. On the other hand, $22 \%$ of respondents think that their biggest problem is the possibility to rise founding for preparing and providing courses to seniors. The problem as the third in order of choice, and that $17 \%$ of respondents chose once again lack of soft skills. Teamwork so important in achieving success should be widely developed (Czapiński, 2015).

In another question, respondents were asked to self-determination on their knowledge related to the use of electronic equipment on a scale of 1 to 7

The chart below has been shown response rate of 6 or 7 or people who have defined their competence as high. 


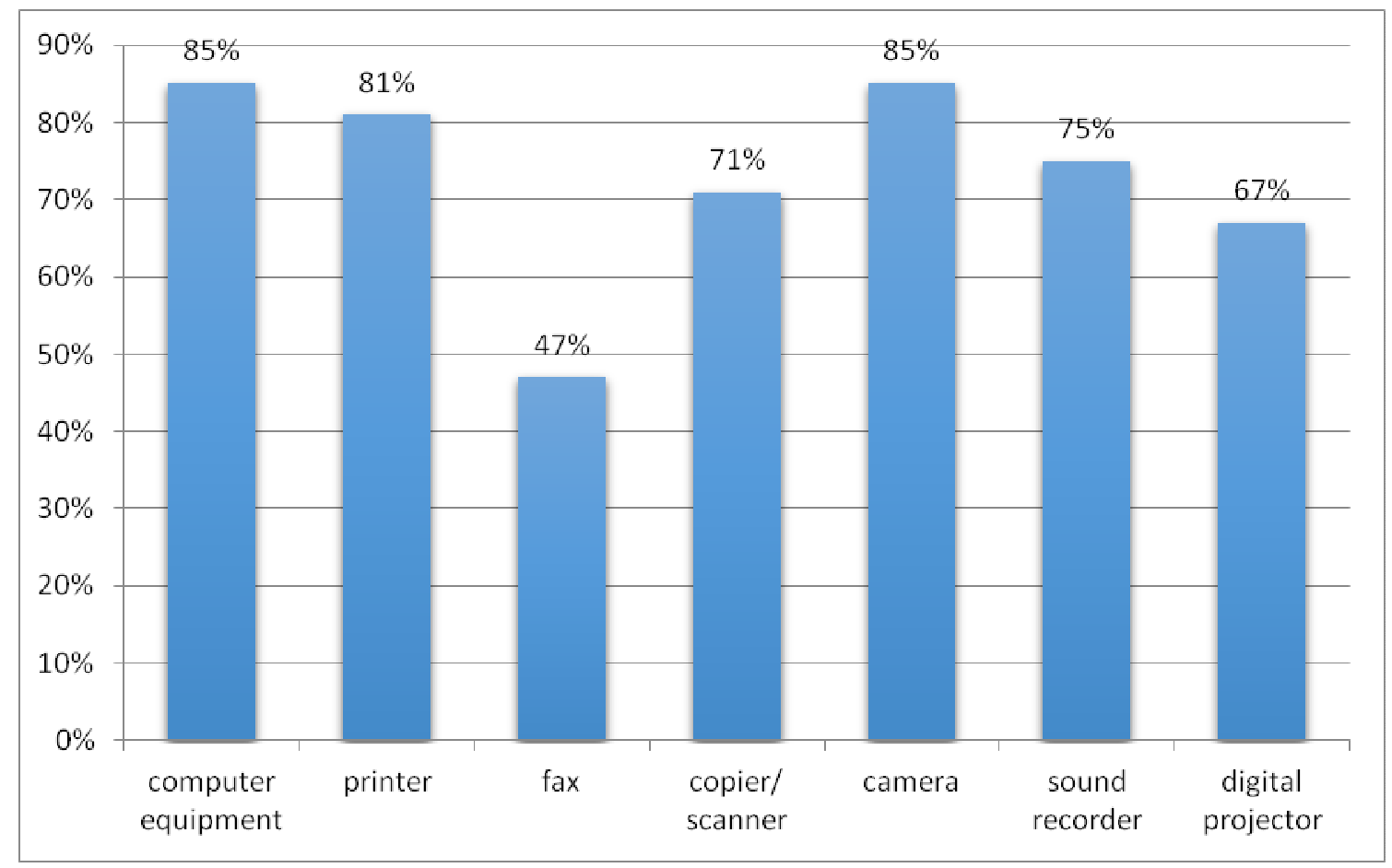

Figure 4 Self-assessment of digital competences

The responses show that employees of Adult education can very well handle the various types of electronic equipment used in education.

It should not be surprising that teachers feel very good to use a computer $(85 \%)$, cameras $(85 \%)$, printers $(81 \%)$. In the end, this is the equipment used by them during their lessons. Also, the fact that less than half (47\%) of teachers can handle the fax is not surprising. This is the kind of equipment "out of date".

Deeper analysis, however, brings interesting thesis. General findings may suggest that women above assess their technical competence of men. This is surprising when confronted with opinions that technical knowledge is greater extent reserved for men. The biggest differences in this section are reflected the self-assessment of knowledge about the sound recorder $\left(\mathrm{Chi}^{2}\right.$ 9,24886, $\mathrm{p}=, 009809) .88 \%$ of women and just over $52 \%$ of men rate their skills of highly. 


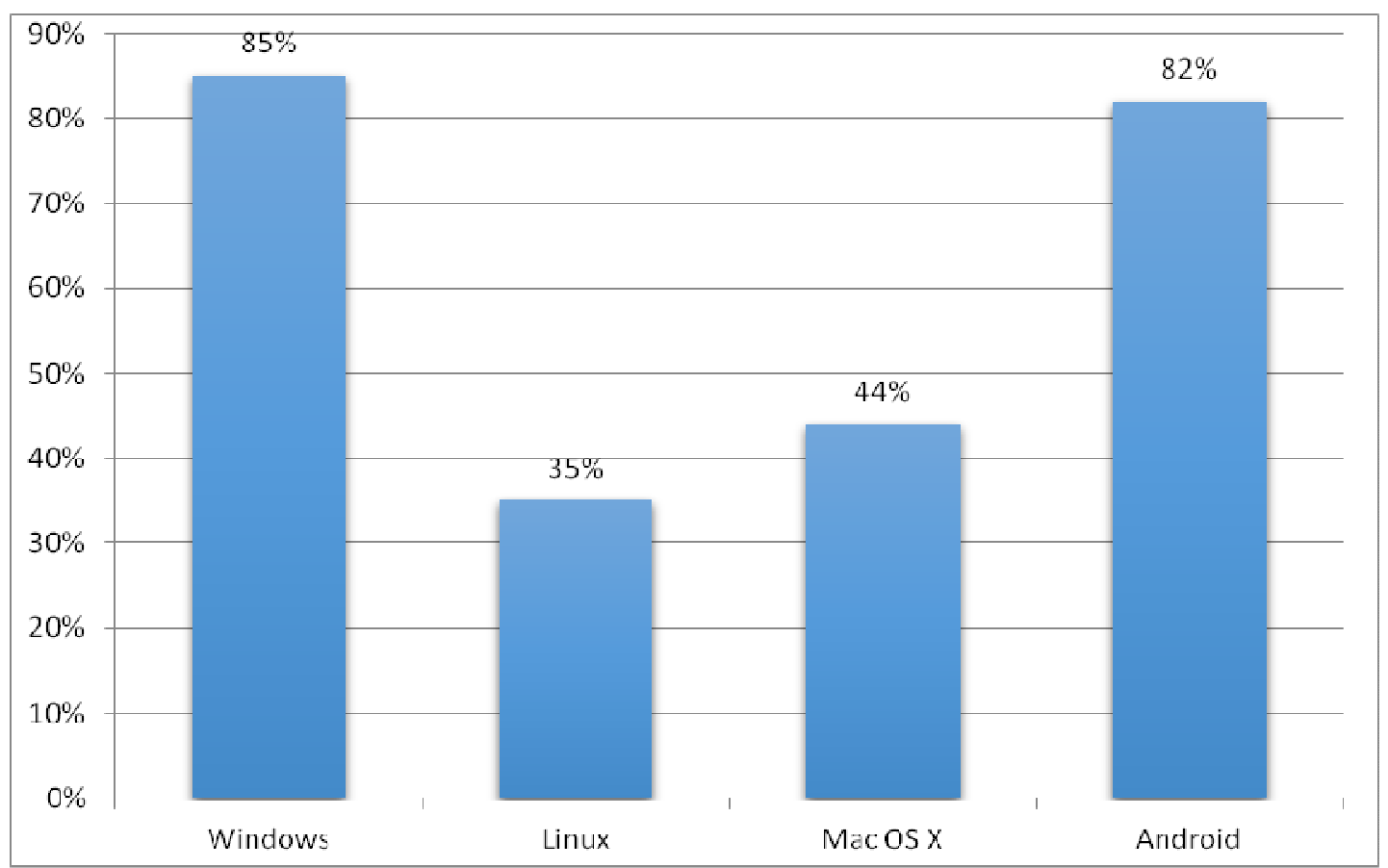

Figure 5 Use of operating systems

Self-assessment using a variety of operating systems for teachers is not surprising. Windows as the operating system installed on the vast majority of PCs and Android as the main system used in mobile phones is widely known in the teaching community. Something to point out is that teachers do not use much Linux even though it is as a free alternative of operating systems.

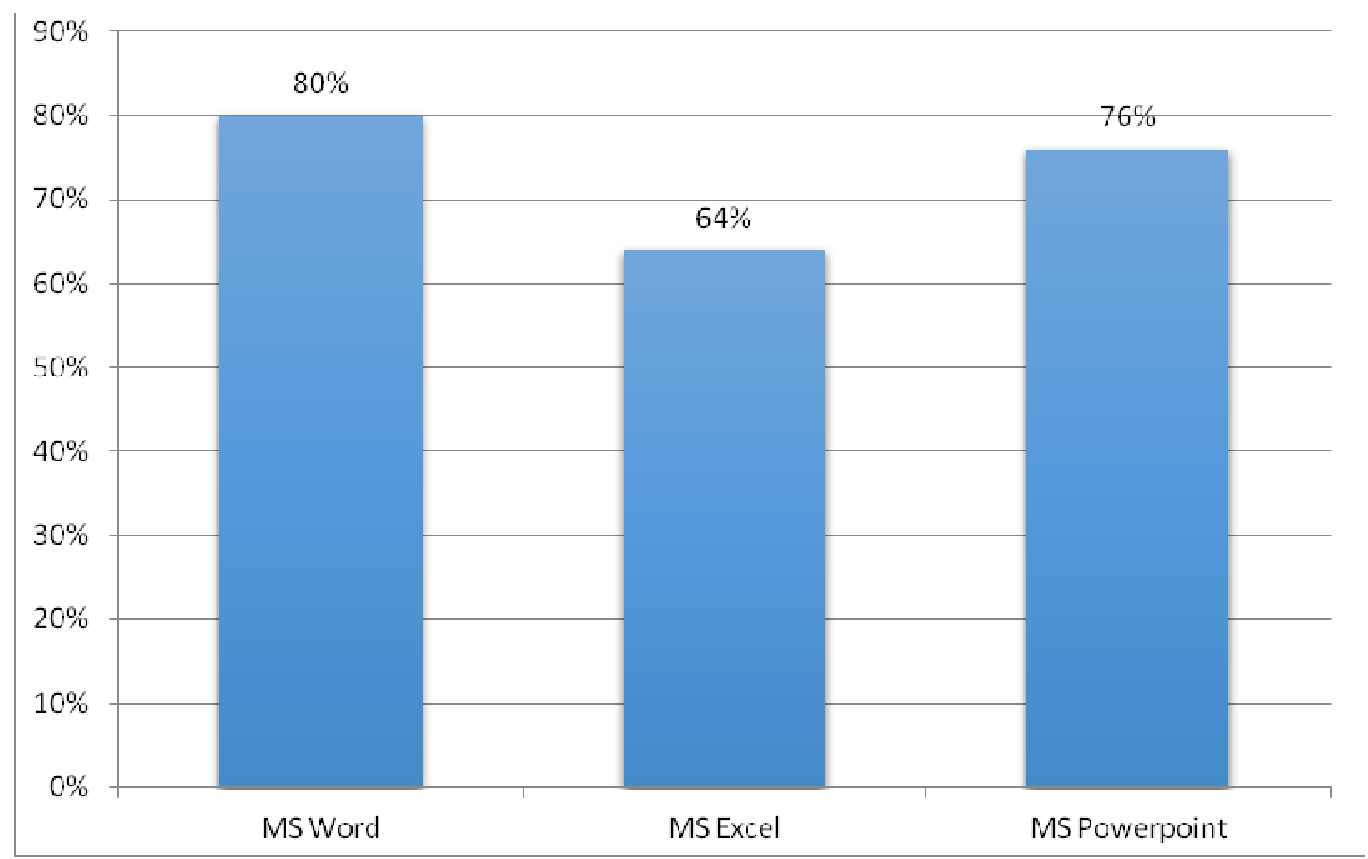

Figure 6 Use of programmes 
Also competence in the most popular office programs do not raise surprise. $80 \%$ of respondents defines its competence as high in the case of a text editor which is MS Word. A little less see them self as an "expert" in preparation for a presentation in PowerPoint (76\%), but only a little less than two-thirds of educators feel very good in working with a spreadsheet which is MS Excel.

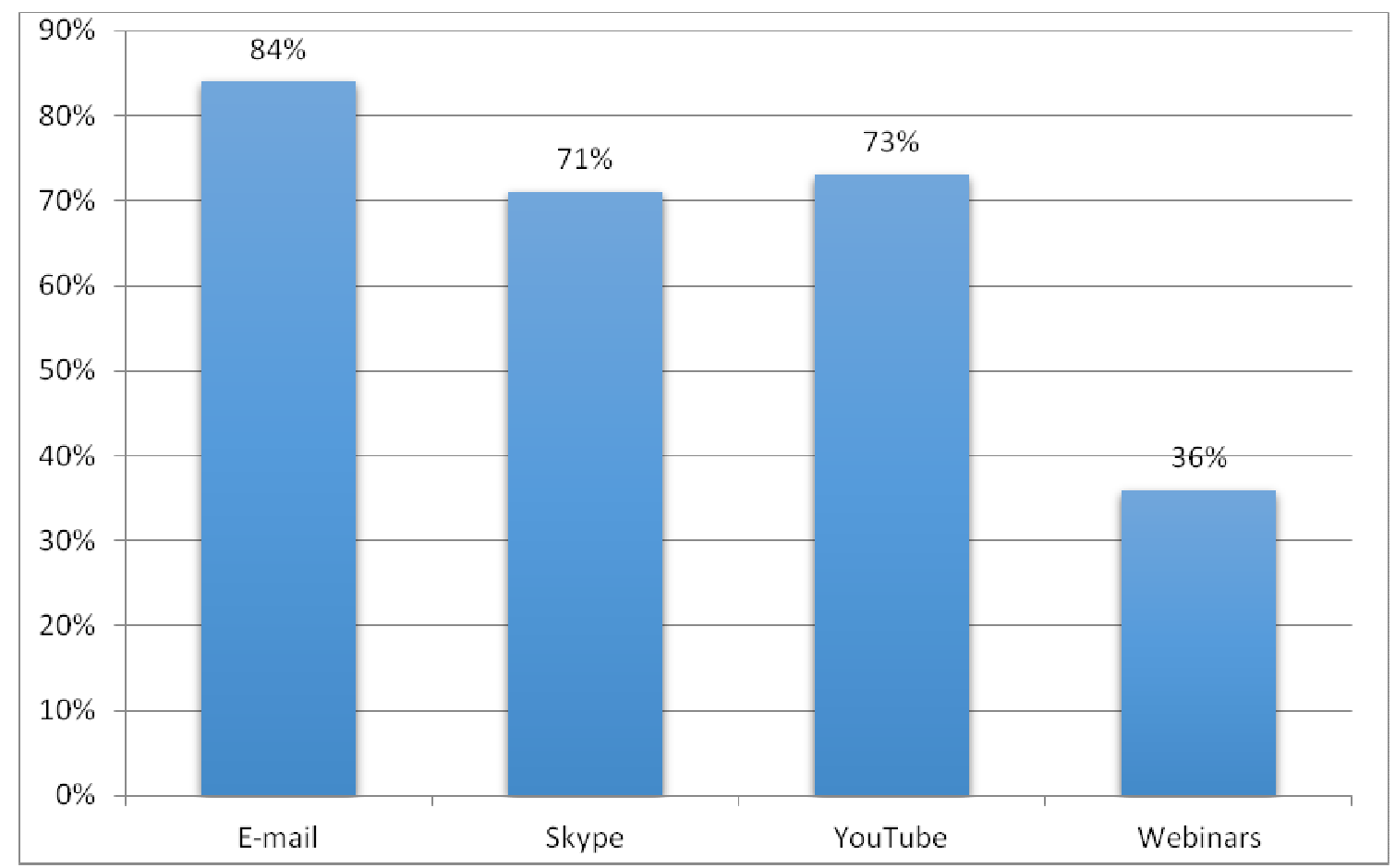

Figure 7 Internet applications

Another issue is dealing with web applications. E-mail in this regard is very well known by $84 \%$ of respondents. The tool is in a very effective way supplanted nowadays traditional mail for obvious reasons. Normal user irritates spam in this tool, however, the advantages of effectively "overshadow" the disadvantage. Skype and YouTube as another contemporary applications for communication and presentation are also highly evaluated the same - at the level - $71-73 \%$. What should certainly be highlighted in the course of selfimprovement is the ability to use webinars or technology to create a presentation or even a conference on-line. Only slightly more than one-third (36\%) determines its competence in this area as very good.

The last questions cover issues related to social networking. 


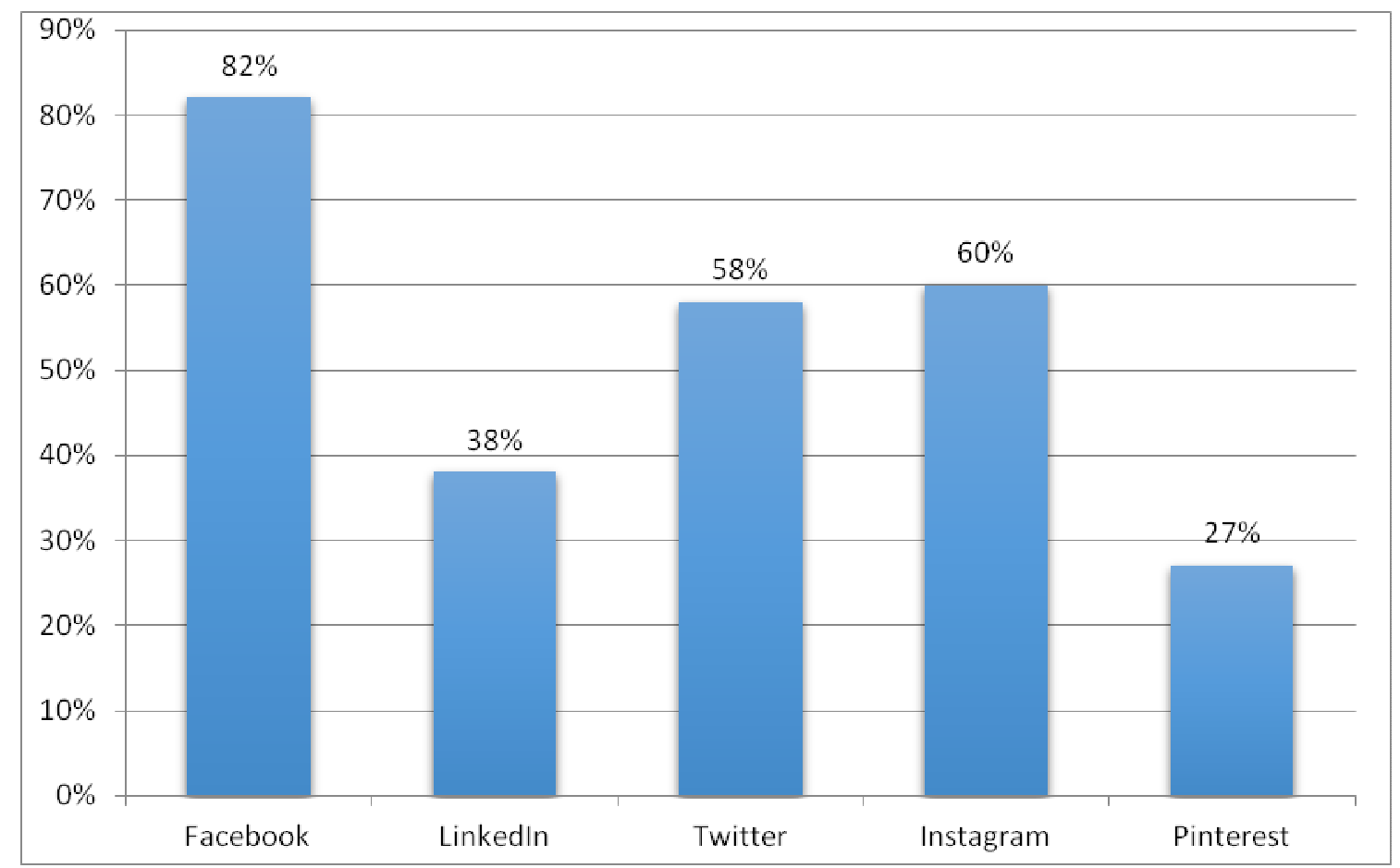

Figure 8 Social networks

The answers confirm today's dominance of the portal which is Facebook. $82 \%$ of respondents identified their knowledge at 6 or 7 in a seven scale on the above subject. Pretty many teachers also recognizes Instagram or web-pages on which shows their photos or short videos.

\section{Conclusion}

The research presents some important outputs necessary for the development and implementation of the second face of the project Upskilled, that is the design of the Open Badges Digital Competence Code for Adult Education. The consortium will design and analyze the Digital Code with inbuilt benchmarks and indicators to define and classify the digital skills necessary for Adult Educators in order to better support and empower adult learning provision especially the ones that are not well served. An on-line survey and consultation with stakeholders will be organized to support the proposed Framework.

What should certainly be highlighted in the research is that our target group has some limitations on e-learning activities and needs of self-improvement on the use of webinars or technology to create a presentation online or even a virtual conference.

Even though the Education System is present at every stage of the Adult Education and has an important impact on the learners, teaching - learning methodologies should be updated. The right to education is guaranteed to each 
person by all kinds of regulations from the Polish Constitution, but activities implemented by governmental and non-governmental organizations, associations and other formal or informal groups must be developed taking into account the target group. It is important also to underline that the Government continuously improve the access and quality of the education for elderly people, who, despite the fact that they do not have a suitable physical condition, still remain efficient mentally and looking forward to gain knowledge and be socially active, follow trends and modern forms of communication.

The research is part of the needs analysis of the target group of the project Upskilled that aims to create an interactive platform which will provide adult learners with the skills in e-learning, e-connectivity and e-communication.

\section{References}

Budny, M., Pogoda, I., \& Szosztakowska, M. (eds.) (2013). Diagnoza dobrych praktyk metod aktywizacji zawodowej osób w wieku 50+ (pp. 17 - 23). Warszawska Wyzsza Szkola Informatyki.

Czapiński, J., \& Panek, T. (eds.) (2015). Diagnoza społeczna 2015. Warunki I jakość życia Polaków/ Social diagnosis 2015. Objective and subjective quality of life In Poland. Quaterly of university of Finance and management In Warsaw. Vol. 9 Is. 4.

Government program ASOS [ASOS], Seniorzy/aktywne starzenie / Rzadowy program ASOS / Ministerstwo Rodziny, Pracy i Polityki Spolecznej. (n.d.). Retrieved January 31, 2017, from https://www.mpips.gov.pl/seniorzyaktywne-starzenie/rzadowy-program-asos

Little, T. D. (Ed.) (2013). The Oxford Handbook of Quantitative Methods, Vol. 2: Statistical Analysis. Oxford University Press.

Senior's Policy Department [DPS]. Seniorzy/aktywne starzenie / Departament Polityki Senioralnej / Ministerstwo Rodziny, Pracy i Polityki Spolcznej. (n.d.). Retrieved January 31, 2017, from http://www.mpips.gov.pl/seniorzyaktywne-starzenie/ departament-polityki-senioralnej/

UPSIKILLED (2016), Upskilling Adult Educators Digital Lead, KA2 - Strategic Partnership in the field of Adult Education Retrieved January 31, 2017, from http://ec.europa.eu/programmes/erasmus-plus/projects/eplus-project-detailspage/?nodeRef=workspace://SpacesStore/a7d0bd10-afd5-49ea-91e8-282c4c1429dd 